\title{
Застосування
}

DOI https://doi.org/10.15407/usim.2019.06.066

UDC 681.513 .7

ANTOYYUK YA.M., researcher, International Research and Training Centre of Information Technologies and Systems of the NAS and MES of Ukraine, Glushkov ave., 40, Kyiv, 03187, Ukraine,

ant@noc.irtc.org.ua

\section{DIAGNOSTIC METHODS AND TRAFFIC MANAGEMENT ON CAMPUS NETWORKS}

The solution to the problem of ensuring a satisfactory level of quality of service for subscribers of the campus network (CS), increasing the values of the Quality of Service and Quality of Experience parameters are necessary for the operational solution of production issues. On the other hand, improving the subscriber's impression of the level of services provided has an additional economic effect. The combination of hardware and software traffic control mechanisms in conditions with the limited bandwidth of the external channel depends on the intellectualization of traffic control policies, the methods of application of which are discussed in this article.

Keywords: network traffic analysis, network security, traffic management policies, classification of network traffic, quality of delivered services, quality of perception, principle of maximum expected utility.

\section{Introduction}

Solving the problems of ensuring a satisfactory level of quality for campus network $(\mathrm{CN})$ subscribers is necessary for the prompt resolution of production issues. On the other hand, improving impressions has an additional economic effect [1]. The basic concepts in solving this problem are Quality of Service (QoS) and Quality of Experience (QoE). The combination of these terms is often used as a synonym for traffic management.

The combination of hardware and software traffic control mechanisms in conditions with limited bandwidth of the external channel depends on the intellectualization of traffic control policies, the methods of application of which are discussed in this article.

The aim of the study is the synthesis of an algorithm for the formation of traffic control policies on a campus network.

The next limit conditions accepted:

- lower bound of QoS parameters for allowed services

- upper bound according to the nomenclature of hardware controls and external channel
- upper bound of financial limits

each of which is characteristic of a modern research structure.

Management is carried out on the basis of the principles of imposing dynamic disciplines - filters of information and service flows, which optimize the state of collision domains and the CS as a whole.

Solution methods. Methods of forming management policies based on a combination of network stability criteria are considered [2]. Also, methods are used to identify and eliminate intra-domain collisions and prioritize classified traffic [3], based on the principle of statistical multiplexing of information flows, in which the bandwidth of the output channel is provided to the input channels as necessary.

Diagnostics of the NC connects QoS and QoE with parameters that affect them [3].

$$
y=\varphi\left(S_{n}\left\{x_{1}, x_{2} \ldots x_{k}\right\}\right),
$$

where - set of characteristics of the components of the COP

- network cable structure (NCS)

- passive equipment (repeaters, hubs)

- active equipment (network cards, switches, routers) 
- servers line resources and network operation centre (NOC)

- work station resources

The structural diagram of the $\mathrm{CN}$ can be represented following the component approach, where each of the components is a combination of components of the previous level. Thus, each of the lower-level components is a potential malfunction. A hierarchical view allows you to get the most comprehensive $\mathrm{CN}$ model for troubleshooting and increase the efficiency of diagnosis.

Building a troubleshooting model is indispensable in systems with a large number of objects, such as the Internet of things [4].

\section{The logic of the formation of management policies}

The iterative process of forming a system model is based on the subscriber's impression of the level of services provided [2]. In turn, the impression and the actual level depends on maintaining a balance between the quality of service and the economic benefit received from the provision of these services. This principle involves intelligent methods of traffic management in the operator's network and is based on the work of special tools that ensure optimal use of resources for a certain type of traffic. To access the internet on campus networks a dedicated communication channel, organized on a switching node is used. When organizing public access, the task is to distribute as much as possible the specific resource, the dedicated communication channel or service, among network participants, taking into account the needs of each client by creating a flexible traffic distribution system.

A channel with a small band width providing general access to the Internet can be completely occupied by the traffic of individual network nodes, as a result of which access to global resources for the rest of its participants will become impossible. Applications such as real-time audio and video, IP-telephony, video conferencing systems need an ever wider band width. It follows that, without a monitoring system for the use of the communication channel, the intensity of these flows in real time depends only on the available channel band- width. A narrow bandwidth or instability of its width leads to a sharp deterioration in the quality of the services provided. This gives rise to a nontrivial task of finding the optimal approach to organizing traffic management if access to information resources is carried out in a network with a small or variable bandwidth of a common communication channel.

When creating traffic management disciplines, it is polite to users to avoid using a traffic management policy based on methods of blocking content otherwise interfering with network applications. Blocking widespread peer-to-peer traffic can save operator money and even improve the quality of service for some users, but it will not be considered a "reasonable" or "fair" policy.

To traffic management, a "reasonable" network policy should have the following qualities.

Justice. A fair network policy provides subscribers and applications with reasonably proportional access tore sources, network bandwidth. Moreover, the type of application used by the subscriber or the information resource that is being accessed does not have a definite value.

Adaptability. Adaptive network policy adapts to cases of congestion, affecting primarily the types of traffic that least affect the subscriber's impression of the quality of the service.

Transparency. A transparent network uses a traffic control policy that is easily explained to the subscriber and can be controlled by him. Existing solutions for implementing a traffic management system can be divided into hardware and software.

- By hardware solutions is meant the use of specialized equipment that performs routing and traffic control. Such hardware routers are superior in technical parameters to software analogues, but due to the high cost, they remain practically inaccessible to small companies that provide Internet services.

- Software solutions are based on the use of a set of applications such as database management systems, traffic control tools, etc., installed on the operating system (OS) of a PC or server computer.

Because of this, it seems advisable to focus on the programmatic approach of traffic management in the network of the telecom operator. Thus, a 


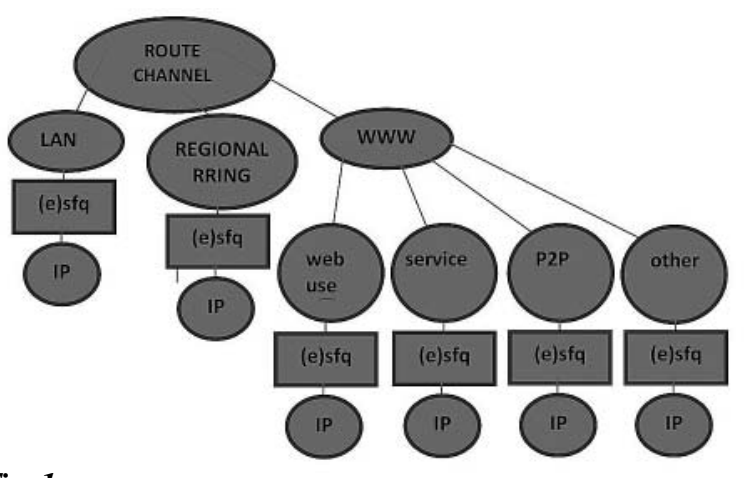

Fig. 1.

conclusion is drawn on the need to develop a traffic management system (TMS), made for the campus network of a real telecommunications operator under the control of a basic computer telecommunication node NOC.

The system has the following requirements:

- ensuring a "reasonable" network policy;

- availability of information flow management mechanisms based on the protocol used. The main requirement is the ability to control P2P (peer-topeer) traffic and traffic going to regional network nodes;

- correspondence of a system of a differentiated QoS implementation model;

- the growth in the number of subscribers in the network should not lead to a complete reorganization of the architecture of the designed system.

All considered solutions are based on using Unix as a server OS. As the OS for the switching node or server, the FreeBSD and Linux systems is selected. This system meets all the requirements and is an open source software product. The choice of distribution is also due to good technical support, expressed in the regular release of updates, and documentation that helps minimize the costs associated with the implementation of the system. A detailed description of the basic concepts, elements, algorithms and traffic management mechanisms in UNIX OS is contained in the corresponding manual [8].

It is possible to build various versions of the SUT architecture. These options have initial properties that imply proportional access of subscribers to network resources and provide for the possibility of generating information flows and managing them based on the data transfer protocols used. The systems under consideration provide classes for P2P traffic and traffic going to regional network resources, forming a "regional ring".

The traffic management system in FreeBSD can be represented as a tree [5]. Depending on the specific discipline used in traffic management, the appearance of the tree may vary. When developing and analyzing the package management system, the class hierarchy of traffic distribution - Hierarchical Token Bucket is used as the main one. This discipline provides high flexibility in management and allows you to define filters that classify traffic and direct it to certain subclasses.

The tree structure of the TMS options is presented in Fig. 1.

The figure shows that several traffic classes are allocated to this system. Stochastic Fairness Queuing is used as a leaf discipline.

A second option may also be considered that separates traffic not only by the type of protocol used but also by destination. Each subscriber is represented in the network in a separate class. In this TMS model, the tariff parameters (guaranteed, maximum transfer rate, priority, etc.) are determined by a separate concrete class corresponding to each client.

In the third version, the Extended Stochastic Fair Queuing algorithm is used as a leaf queue processing algorithm. This discipline provides more options for setting up a queue, as opposed to SFQ. Having the ability to control the used hash algorithm, the user can achieve a more even distribution of bandwidth.

When developing the TMS for the campus network, an assessment of the fairness of the distribution of resources in the network was used as the main indicator of the effectiveness of the system.

For analysis, a test bench was designed and a situation was simulated when the system is installed on a switching node (Fig.2).

The eth 0 interface of the router is directed to the local network and eth1 to the Internet.

The provider's network contains peer-to-peer traffic and traffic destined for the "regional ring" defined by the list of IP addresses. A quantitative assessment of the fairness of the distribution of 
network resources can be calculated as the standard deviation of the information transfer rate for each class and each client at a certain point in time. In the study, the information transfer rate for each specific client in the network at an arbitrary point in time is a random variable generated by the traffic generator. In this case, the statistical characteristic of the distribution of a random variable will show the average degree of variation in the values of the information transfer rate for each client relative to the average value.

$$
\sigma=\sqrt{\frac{1}{n} \sum_{i=1}\left(x_{i}-\bar{x}\right)^{2}} ; \bar{x}=\frac{1}{n} \sum_{i=1}^{n} x_{i}=\frac{1}{n}\left(x_{1}+\ldots+x_{n}\right),
$$

where $x_{i}-$ is the value of the information transfer rate for the $i$-th client at time $t$; $n$ - is the sample size.

This estimate can be calculated for each "instant set" of transmission rates in client classes. The value of the parameter $n$ varies in time, depending on whether the information was transmitted for the client at a particular moment. The fairest distribution of traffic is characterized by a value of zero or close to zero.

Thus, taking into account the growth in the consumption of telecommunication services and network services, the task is to develop and implement intelligent methods for organizing network traffic management based on a dynamic analysis of a set of key sections of the CS infrastructure.

This analysis will allow you to adapt the $\mathrm{CN}$ to changing traffic flows and traffic unevenness.

The construction of the SCS is determined by the structure, the interaction of which with the external environment allows us to identify the functions of the system as a manifestation of its properties in time. Therefore, the structure of the system and its functions are connected through a spatio-temporal relationship between its elements.

A separate study is DPI-based QoS and QoE control [6].

When constructing such systems for combining them into a single TSM, it is necessary to solve the problem of technological and information integration, which must be carried out at the transport, infrastructure, system and application levels. As part of this process, it is necessary to ensure the in-

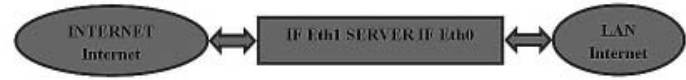

Fig.2

tegration of interfaces, data and applications. Only when solving the whole range of integration tasks can it be possible to build a modern integrated corporate-level TSM that can effectively solve business problems by with the chosen business model and organization development strategy. The search for the optimal, from the point of view of the given criteria solution, determining the configuration of the integrated TSM control system, must be carried out on a finite set of alternatives formed by sets of valid input data describing the corresponding system [7].

For example, at the application level, there is a set of questions that arise when using a switched environment [7]:

- load level of each port?

- the level of the network model where the source of errors is located

- $\quad$ specification of the source of the broadcast storm (propagation of incorrectly formed broadcast messages)?

- the adequacy of the MAC address table?

- list of stations connected to this port?

- the level of speed limits of any protocol or port on the switch?

- VLAN port definition?

The switch device defines a separate collision domain for each port[4]. If a hub is connected to the switch port, the collision domain can grow to the size that is maximum acceptable for this implementation of the Ethernet-standard. However, due to the lower cost of switches, most new networks have only one station per port. The switch itself becomes part of a single broadcast domain that includes other switches. If the network uses Layer 3 switch features, then multiple broadcast domains are created equal to the number of VLANs. In the extreme case, if the switch parameters allow, each port can be configured as a separate broadcast domain.

A similar scheme can be proposed for software implementations of SUT [8].

The formal presentation of the corporate integrated information system as a set of mathemati- 
cal models defines the main problem. When constructing an integrated SUT - in the general case, it is impossible to find a global extremum and/or an optimal solution, in general, for the system, due to its "bias" for each of the subsystems. Therefore, about integrated SUT, we can talk about quasioptimal options. The final choice of option when forming an integral criterion for evaluating the effectiveness of a corporate integrated information system for implementation is made according to an additional criterion.

In the general case, the search for the optimal alternative can be carried out according to the following algorithm.

1. Preliminary data preparation. Separation of the data sample into the training and control parts.

2. To obtain a pool of objects of the same type, cluster alternatives.

3. Using mathematical calculations and training models, get performance criteria as a function of particular performance indicators. We use the data of the training sample.

4. To determine the approximation error on the data of the control sample, which are interpreted as values that are inverse to the importance of the models.

5. We calculate the values of the integral efficiency criterion for each alternative and determine the optimal alternative.

\section{Results}

Schemes have been developed that visualize basic control policies based on various types of traffic classification and methods for diagnosing collisions at the 2 nd, 3 rd routing levels in standard network models.

\section{Conclusions}

Based on the results, it was concluded that the second version of TMS has the best assessment of justice. It both integrates the most even distribution of traffic regardless of the number of open connections by each client. Unlike the first and third options, the second option provides for the presence of several tariff plans at the same time with the task of guaranteed and maximum speed values. In this case, traffic redistribution will be carried out in proportion to the guaranteed rates set for each class. Based on the solution of the problem of prioritizing the selected data classes, traffic management methods can be organized, as shown in the examples.

The formation of the QoE assessment is based on the quality of the network service itself and the utility function, which reflects the satisfaction of the service provided, depending on the bandwidth of the communication channel.

When solving the problems of optimizing the use of the network, it is important, along with theoretical, difficult to implement in a real network, control algorithms to take into account practical optimization tools provided by the developers of operating systems and the types of traffic generated by various network applications on aggregation nodes. Like any complex TMS system consists of many subsystems, united by a set of heterogeneous relationships. The solution to the problem of choosing the optimal alternative depends on the spectrum of tasks that the $\mathrm{CN}$ will solve, and its effectiveness will be determined by the existing structure and management strategy, which consists in the efficient allocation of resources and the need to select from a variety of objects, elements and the relationships between them.

\section{REFERENCES}

1. Gritsenko, V.I. Oursatiev, A.A., 2017. "Sovremennye informatsionnye tekhnologii hraneniya dannyh". Kiev "Naukovadumka”, 250 p. (In Russian).

2. Kuzmin, V.V., Semashko A.V., 2015. Metody upravleniya trafikom v kampusnykh setyakh operatora svyazi, [online]. Available at: <https://elsv.ru/assets/uploads/2015/07/kuzmin_i.pdf > [Accessed 11 Oct. 2019]. (In Russian).

3. Diagnostics of local and corporate computer networks, [online]. Available at: $<$ https://dl.nure.ua/pluginfile.php/1152/ mod_resource/content/1/01.pdf> [Accessed 11 Oct. 2019]. (In Russian).

4. Internet of things - what is it, [online]. Available at: <https://habr.com/ru/post/149593/> [Accessed 11 Oct. 2019]. (In Russian). 
5. Arkhitekturakommutatorov, [online]. Available at: <http://iptcp.net/arkhitektura-kommutatorov.html> [Accessed 11 Oct. 2019]. (InRussian).

6. DPI Technology Brief - Deep Packet Inspection, [online]. Available at: $<$ https://habr.com/ru/post/111054/> [Accessed 11 Oct. 2019].

7. Diagnostikakommutiruyemykhsetey, [online]. Available at: <https://www.icsgroup.ru/library/publications/detail. php? ID $=634>$ [Accessed 11 Oct. 2019]. (InRussian).

8. LARTC, [online]. Available at: <https://www.opennet.ru/docs/RUS/LARTC > [Accessed 11 Oct. 2018].

Received 28.11.2019

\section{ЛІТЕРАТУРА}

1. Гриценко В.И. Усьатьев, А.А., 2017. «Современные информационные технологии хранения данных».

Киевская «Науковадумка», 250 р.

2. Кузьмин В.В., Семашко А.В., 2015. Методы управления трафиком в кампусных сетях оператора связи, [онлайн]. URL: <https://elsv.ru/assets/uploads/2015/07/kuzmin_i.pdf>

3. Диагностика локальных и корпоративных компьютерных сетей, [онлайн]. URL: $<$ https://dl.nure.ua/plugin-

file.php/1152/mod_resource/content/1/01.pdf>.

4. Интернет вещей - что это. URL: <https://habr.com/ru/post/149593/>.

5. Архитектура коммутаторов. URL: <http://iptcp.net/arkhitektura-kommutatorov.html $>$.

6. Краткое описание технологии DPI - Deep Packet Inspection. URL: <https://habr.com/ru/post/111054/> .

7. Диагностика коммутируемых сетей. URL: <https://www.icsgroup.ru/library/publications/detail.php?ID=634> .

8. LARTC. URL: <https://www.opennet.ru/docs/RUS/LARTC >.

Надійшла 28.11.2019

Антонюк Я.М., н.с., Міжнародний науково-навчальний центр

інформаційних технологій і систем НАН і МОН України,

просп. Академіка Глушкова, 40, Київ 03187, Україна,

ant@noc.irtc.org.ua

\section{МЕТОДИ ДІАГНОСТИКИ ТА КЕРУВАННЯ ТРАФІКОМ У КАМПУСНИХ МЕРЕЖАХ}

Вступ. Забезпечення задовільного рівня якості обслуговування для абонентів кампусної мережі (КМ), підвищення значення параметрів Quality of Service $i$ Quality of Experience є необхіднимиі для оперативного вирішення виробничих питань. Додатковий економічний ефект має поліпшення думки абонента про рівень наданих послуг. Комбінування апаратних і програмних механізмів управління трафіком в умовах з обмеженою пропускною здатністю зовнішнього каналу залежить від інтелектуалізації політик управління трафіком, засоби застосування яких розглядаються в цій статті.

Мета. Метою дослідження є синтез алгоритму формування політик управління трафіком кампусної мережі. Беруться до уваги умови обмеження коштів апаратного управління та зовнішнього каналу, а також фінансових лімітів, що характерно для сучасної дослідницької структури.

Управління здійснюється на основі принципів накладення динамічних фільтрів інформаційних і службових потоків, які оптимізують стан колізійних доменів і КС загалом.

Методи. Розглянуто метод формування політик управління на основі комбінування критеріїв стабільності роботи мережі, виявлення та усунення внутрішньо-доменних колізій і пріоритизації класифікованого трафіку, заснованих на принципі статистичного мультиплексування інформаційних потоків.

Результати. Розроблено схеми, що візуалізують базові політики управління на основі різних типів класифікації трафіку та способів діагностики колізій на 2-му таі 3-му рівнях маршрутизації в стандартних мережевих моделях.

Висновки. На основі розв'язання задачі пріоритизації виокремділених класів даних можуть бути організовані методи управління трафіком, що показано на прикладах. Формування оцінки $Q o E$ відбувається на основі якості роботи самої мережевої послуги та функції корисності, що відображає задоволеність наданим сервісом в залежності від пропускної здатності каналу зв'язку. Вирішуючи завдання оптимізації, важливо, поряд із 
теоретичними, важко реалізуємими в реальній мережі, алгоритмами управління, які важко реалізувати в реальній мережі, враховувати практичні засоби оптимізації, передбачені розробниками операційних систем, а також типи трафіку, що генеруються різними мережевими додатками на вузлах агрегації.

Ключові слова: аналіз мережевого трафіку, мережева безпека, політики управління трафіком, класифікація мережевого трафіку, якість послуг, що поставляються (наданих послуг), якість сприйняття, принцип максимальної очікуваної корисності.

Антонюк Я.М., н.с., Международный научно-учебный центр информационных технологий и систем НАН и МОН Украины, просп. Академіка Глушкова, 40, Киев 03187, Украина, ant@noc.irtc.org.ua

\section{МЕТОДЫ ДИАГНОСТИКИ И УПРАВЛЕНИЯ ТРАФИКОМ В КАМПУСНЫХ СЕТЯХ}

Вступление. Решение задачи обеспечения удовлетворительного уровня качества обслуживания для абонентов кампусной сети, повышение значений параметров Quality of Serviceu Quality of Experience необходимы для оперативного решения производственных вопросов. С другой стороны, улучшение впечатления абонента об уровне предоставляемых услуг имеет дополнительный экономический эффект. Комбинирование аппаратных и программных механизмов управления трафиком в условиях ограниченной пропускной способности внешнего канала зависит от интеллектуализации политики управления трафиком, способы применения которых рассматривается в данной статье.

Цель. Целью исследования является синтез алгоритма формирования политик управления трафиком в кампусной сети. Принимаются условия ограничения: средств аппаратного управления и внешнего канала, а также финансовых лимитов, характерных для современной исследовательской структуры. Управление осуществляется на основе принципов наложения динамических фильтров информационных и служебных потоков, оптимизирующих состояние коллизионных доменов и кампусной сети в целом.

Методы решения. Рассмотрен метод формирования политик управления на основе комбинирования критериев стабильности работы сети, выявления и устранения внутредоменных коллизий и приоритизации классифицированного трафика, основанные на принципе статистического мультиплексирования информационных потоков.

Результаты. Разработаны схемы, визуалзирующие базовые политики управления на основе различных типов классификации трафика и способов диагностики коллизий на 2-м, 3-м уровнях маршрутизации в стандартных сетевых моделях.

Выводы. На основе решения задачи приоритизации выделенных классов данных могут быть организованы методы управления трафиком, что показано на примерах.

Формирование оценки $Q o E$ происходит на основе качества работы самой сетевой услуги и функции полезности, отображающей удовлетворенность предоставляемым сервисом в зависимости от пропускной способности канала связи.

При решении задач оптимизации важно наряду с теоретическими,трудно реализуемыми в реальной сети,алгоритмами управления, учитывать практические средства оптимизации, предусмотренные разработчиками операционных систем также типы трафика, генерируемого различными сетевыми приложениями на узлах агрегации.

Ключевые слова: анализ сетевого трафика, сетевая безопасность, политики управления трафиком, классификация сетевого трафика, качество предоставляемых услуг, качество восприятия, принцип максимальной ожидаемой полезности . 